\title{
PARA ONDE VOU COM A MINHA FAMÍLIA? UMA ETNOGRAFIA SOBRE PROJETOS COLETIVOS E MIGRAÇÃO VENEZUELANA EM MANAUS (BRASIL)
}

\author{
Where do I go with my family? An ethnography on collective projects \\ and Venezuelan migration in Manaus (Brazil)
}

\author{
Sandro Martins de Almeida Santos* \\ Ivón José Lo Bianco Meza**
}

\begin{abstract}
Resumo. O artigo apresenta o "projeto migratório" e as estratégias acionadas por uma família venezuelana em sua trajetória no Brasil. A jornada é marcada por preocupações coletivas, desde a intenção inicial de migrar, passando pelas dificuldades para reunir os entes queridos em Manaus, e chegando à decisão de se estabelecerem. Os dados permitem problematizar um tema clássico das ciências sociais, os compromissos entre indivíduos e o grupo, enfatizando a solidariedade duradoura e um imaginário compartilhado de mútuo pertencimento implicados nas relações de parentesco. O norte da discussão teórica é a conformação de um "projeto familiar" que articula o local, o nacional e o transnacional. Ao final, refletimos sobre as transformações individuais e coletivas implicadas no processo migratório.
\end{abstract}

Palavras-chave: migração venezuelana; família; projeto; Manaus.

\begin{abstract}
This paper presents the "migratory project" and strategies triggered by a Venezuelan family in their trajectory in Brazil. The journey is marked by collective concerns, from the initial intention to migrate, going through the difficulties to bring loved ones together in Manaus, up to the decision to settle down. The data allow us to problematize a classic social science theme, the commitments between individuals and the group, emphasizing the enduring solidarity and a shared imaginary of mutual belonging implied in kinship relations. The theoretical discussion is guided by the framing of a "family project" articulating the local, the national and the transnational levels. At last, we reflect on the individual and collective transformations involved in the migration process.
\end{abstract}

Keywords: Venezuelan migration; family; project; Manaus.

\footnotetext{
Professor do Departamento de Antropologia e do Programa de Pós-Graduação em Antropologia Social da Universidade Federal do Amazonas (UFAM). Manaus, AM, Brasil. E-mail: sandro. almeida@gmail.com. Orcid: https://orcid.org/0000-0001-7829-1731.

** Mestranda no Programa de Pós-Graduação em Antropologia Social da Universidade Federal do Amazonas (UFAM). Manaus, AM, Brasil. E-mail: ijlobianco@gmail.com. Orcid: https://orcid. org/0000-0001-5129-8773.
} 


\section{Introdução ${ }^{1}$}

O recente fluxo de pessoas venezuelanas com destino aos países vizinhos, a partir de 2013, contribui para iluminar o debate acerca da migração enquanto um "projeto familiar". Desde um ponto de vista analítico, entendemos a noção de projeto como uma mobilização e coordenação de esforços coletivos em torno de uma causa compartilhada, em determinados momentos e lugares (Tsing, 2008; Velho, 2013b). No caso das famílias de migrantes transnacionais, as ações concorrem no sentido de viabilizar o deslocamento de indivíduos entre as fronteiras nacionais bem como garantir a continuidade dos cuidados à distância. Quem vai e quem fica são decisões tomadas em grupo, assim como a duração da permanência no local de destino é condicionada pelas necessidades daqueles que ficaram na origem. A possibilidade de reunião familiar no país de destino ou mesmo o retorno também acompanham essa mesma lógica de interdependência entre vontade individual e necessidades do grupo.

Os movimentos migratórios de coletivos que se autorreconhecem como "família" vêm sendo, nas primeiras décadas do século XXI, tema de pesquisas que atestam a existência de uma diversidade formidável de "projetos familiares" emaranhados em teias globais (Bryceson, Vuorella, 2002; Baldassar, 2008; Pavez-Soto, 2017; Pedone, 2008; Levitt, 2001; Lobo, 2012; Machado, 2015; Vasconcelos, Santos, 2017). As diferentes circunstâncias políticas, necessidades econômicas e sonhos descrevem variadas experiências migrantes: crianças que viajam sozinhas ao encontro de um parente desconhecido; adultos que mudam de continente para trabalhar e enviar recursos para os cuidados de crianças e/ou idosos; mulheres que migram com seus filhos; utopias comunitárias transnacionais; entre outros. Não existem protótipos ou tipologias para definir um "projeto migratório familiar". As relações, as motivações, trajetórias e estratégias possíveis perfazem um leque de alternativas tão amplo quanto as inumeráveis culturas de parentesco inventariadas pela Antropologia (Carsten, 2001). A experiência que nos toca debater neste artigo é a de uma família urbana nuclear heteronormativa, com três filhos, na qual os cônjuges projetam juntos o destino do coletivo.

Trazemos o caso da "família" Jimenez², originária de Maracay, Venezuela, hoje residente na cidade de Manaus, Brasil. A experiência dessas pessoas nos permite refletir sobre a importância de uma decisão tomada coletivamente, tendo como motivação o bem-estar dos membros mais jovens desse agregado social. O pai viaja primeiro, em 2014, contando com as economias da avó materna. Tentou estudar e trabalhou em condições precárias. A mãe se juntou a ele, trazendo os dois filhos pequenos. As coisas não deram certo, a mulher retornou à Venezuela. Quando o marido conseguiu o primeiro emprego com carteira assinada, ela viajou

\footnotetext{
1 Agradecemos a leitura atenciosa da antropóloga lana Vasconcelos que teceu críticas a uma versão preliminar deste artigo.

2 Os nomes próprios utilizados ao longo do artigo são fictícios.
} 
para o Brasil novamente com as crianças. Passados alguns anos, melhor adaptados à realidade no país-destino, os adultos ingressaram na universidade para cursar pós-graduação. Engravidaram. Em 2018, a bebê chegou para reforçar os laços do grupo com o solo brasileiro.

Atualmente, a senhora Jimenez realiza pesquisa de mestrado sobre os desafios enfrentados por migrantes venezuelanos/as no tocante à condução de seus projetos de vida em Manaus. Os dados aqui apresentados compõem fragmentos de sua trajetória migratória e refletem situações similares observadas em pesquisa de campo com outras famílias. O texto é elaborado em coautoria com seu professororientador, um misto de reflexão autoetnográfica e observação participante, alimentada pela familiaridade construída na solidariedade entre aluna e professor.

$\mathrm{O}$ excesso de proximidade coloca uma encruzilhada aos autores. Por um lado, oferece a oportunidade de trabalhar dimensões subjetivas "de dentro" do corpo que vive a experiência bem como "compreender realidades escondidas pela vivência de situações de vulnerabilidade" (Costa, 2017, p. 290). Por outro, existe o risco de "naturalizar" os eventos tendo em vista um olhar por demais familiarizado com o contexto. Impõe-se, portanto, o desafio de "confrontar intelectualmente, e mesmo emocionalmente, diferentes versões e interpretações existentes a respeito dos fatos" (Velho, 2013a, p. 78). Como alerta Marilyn Strathern (2014), o exercício da autoantropologia não pode ser mera descrição de idiossincrasias individuais, tampouco a proximidade com a realidade estudada garante a inteligibilidade necessária para comunicar conhecimento aos/às leitores/ as. "Colocar-se na posição de autor/a é testemunhar o mundo através de olhos diferentes" (Strathern, 2014, p. 150). Esse olhar diferente, autoral, é cocriado aqui por meio do entrelaçamento entre a vivência pessoal de uma e as proposições analíticas e questionamentos do outro.

O artigo está organizado no sentido de, primeiramente, apresentar as trajetórias e as estratégias acionadas pelos Jimenez em seu percurso migratório, sem perder de vista as relações de parentesco. Todo o projeto migratório se encontra, no caso em tela, marcado por preocupações coletivas, desde a decisão de viajar ao Brasil, o investimento realizado para financiar a primeira viagem, até as sucessivas tentativas e erros para reunir os entes queridos em Manaus. Num segundo momento, analítico, somos levados a problematizar os compromissos entre os indivíduos e os coletivos, localizando um imaginário compartilhado e as relações duradouras de afetividade e solidariedade que permitem às pessoas se reconhecerem mutuamente enquanto uma família, enfatizando seus laços de proximidade e presença no trânsito entre as fronteiras nacionais. O norte da discussão teórica é a conformação de um "projeto" que mobiliza diferentes agências e articula o local, o nacional e o global. Por fim, à guisa de considerações finais, retomamos o tropo da metamorfose (Velho, 2013b) para refletir sobre as transformações individuais e coletivas implicadas no processo migratório. 


\section{A saga da família Jimenez}

O menino Enrique nasceu na clínica da Cruz Vermelha no centro de Maracay, no dia 17 de maio de 2013. Coincidentemente, o mesmo ano em que Nicolás Maduro tomou posse como presidente para o período 2013 - 2019. Os pais, Miguel e Rosa, sentiam o preludio de que as condições políticas e econômicas tendiam a piorar, assim que a tristeza era combatida com o sentimento de que deveriam sair do país. Em 2013, contudo, a migração ainda não havia produzido testemunhos sobre as experiências de viver nos países vizinhos, porque os venezuelanos não fugiam massivamente do país. A Venezuela, historicamente, foi um país acostumado a receber imigrantes e só recentemente o fluxo de emigração começou acontecer com maior visibilidade.

Pesquisadores venezuelanos dividem o recente movimento migratório em três "ondas" principais: a "migração em busca de oportunidades" (2000-2012); "desesperança crescente" (2012-2015); e a "migração do desespero" (2015 em diante). As distintas ondas migratórias estão relacionadas com diferentes perfis socioeconômicos que condicionam tanto a motivação para sair quanto a seleção do país-destino. A primeira onda carregou profissionais altamente qualificados e empresários com destino aos Estados Unidos e à Europa; a segunda levou trabalhadores qualificados, técnicos e estudantes, com destino aos Estados Unidos, Europa e América Central; já a terceira onda é caraterizada por uma presença crescente das classes populares e indígenas em direção aos países da América do Sul (Paez, 2016; Vivas, Paez, 2017). Em 2013, portanto, ainda não se delineava o movimento denominado "migração do desespero". Existiam dúvidas e pensamentos negativos, uma "crescente desesperança" (Vivas, Paez, 2017, p. 2), mas ninguém poderia antecipar com detalhes o que significaria buscar refúgio na Colômbia, no Brasil ou em outros países sul-americanos.

O casal Jimenez trabalhava como advogados naquela época. O esposo entregou o escritório alugado e com a devolução da caução comprou uma quantidade enorme de fraldas. O maior medo da esposa era ficar sem fralda ou leite para as crianças. Naquele mesmo ano prepararam uma viagem para Sicília, Itália. "Sim, o pais numa crise econômica brutal e nós viajando para Itália", conta Rosa. O governo venezuelano, por meio de políticas cambiais, mantinha um preço fictício do dólar oficial. É como se o governo hoje vendesse um dólar por 50 centavos de real. Muitas pessoas que tinham poupança em dólares viajavam, sobretudo para que a venda daqueles dólares fosse aprovada pelo governo.

É desta maneira que muitos venezuelanos viajavam a outros países entre os anos 2010-2015, para fazer o que se chamava de raspar tarjeta ou, traduzindo literalmente, passar o cartão. O venezuelano turista deixava uma porcentagem na loja e o comerciante entregava uma quantidade em dinheiro vivo, transações que o casal fez na Itália com a finalidade de levantar recursos para migrar ao Brasil. O venezuelano que raspava tarjeta em Lima ou em Santiago nos anos 
2010-2015 nunca imaginou que voltaria para aquelas mesmas cidades a trabalhar como garçom.

No ano de 2013 a Venezuela era um país polarizado, havia muitos descontentes, mas a morte do líder Hugo Chávez estava no pensamento de seus seguidores que tinham recebido o chamado de ser fieis ao novo governo. $\mathrm{O}$ agravamento das condições econômicas e sociais levariam o país a uma situação de enfrentamento entre povo e forças governamentais. Uma parcela significativa da população venezuelana desejava um profundo cambio de governo. Desde o ponto de vista do casal, "a frustração que não esgotou pela via eleitoral nem pela via de manifestações populares extravasou rodoviárias e aeroportos por todo o país".

Rosa, que é coautora deste artigo, foi parte dessa realidade. Ao voltar da Itália, seguiriam para o Brasil, uma história que se multiplicava por milhares no país. Já no voo de ida La Guaira - Roma havia pessoas que planejavam ficar na Itália. Representavam, ainda, a primeira onda de emigrantes (em busca de oportunidades), descendentes de italianos e classe média alta. Naquela época o governo venezuelano podia fazer e fazia com frequência comentários do tipo: "que as pessoas viajavam por prazer, que aquilo era sinal de que a Venezuela era um país rico, que eram emigrantes filhinhos de papai e mamãe".

Retornados da viagem, o próximo destino do casal Jimenez era o Brasil. Rosa já conhecia Boa Vista desde pequena quando viajava com o pai até o estado de Roraima e depois, no ano 2006, conheceu Manaus por meio de manauaras que eram recebidos em sua casa em Cumaná, cidade portuária da qual os brasileiros partiam para a ilha Margarita. Assim foram construídas muitas amizades com o país vizinho, ao ponto de que a família Jimenez visitou Manaus no ano 2009 com um destes grupos de brasileiros e ficaram por três meses. Já em março 2014, o cenário era outro. A decisão era viajar definitivamente ao Brasil com a intenção de ficar. O maior atrativo da cidade era a expectativa criada pela excelente acolhida recebida em anos anteriores.

Percebe-se aqui uma certa extensão da faixa de fronteira entre Brasil e Venezuela. A grande distância entre Manaus ou Boa Vista e o litoral brasileiro faz com que as praias de água cor turquesa da Ilha Margarita sejam destino frequente para turistas amazonenses e roraimenses, assim como a cidade de Manaus há décadas é frequentada por venezuelanos/as para o turismo de compras. Boa Vista, por sua vez, participa desde os anos 1980 de um circuito de comércio, pessoas e serviços ligados à atividade garimpeira que existe tanto do lado venezuelano, onde a pequena mineração é legalizada, como do lado brasileiro, em que resiste enquanto atividade ilegal (Vasconcelos, Santos, 2017).

Voltando à trajetória da família Jimenez, o esposo conseguiu um visto de estudante para cursar especialização em Psicologia Jurídica numa faculdade particular em Manaus e todos/as na família nuclear receberam vistos de acompanhantes. Tanto o visto de estudante como de acompanhante resultavam 
em condição jurídica insuficiente na hora de trabalhar ou exercer alguma atividade remunerada. Apenas com o visto de estudante, impedido de conseguir algum trabalho formal, Miguel passou a vender água em esquinas da cidade de Manaus. Sem dinheiro para pagar a Pós-Graduação, foi necessário abandonar o curso. "Como vou poder ajudar a minha família desse jeito?", o marido se questionava.

A temporada de venda de água nas ruas foi um episódio difícil, houve muito choro, mas o casal evitava brigas. Nessa época, Rosa retornou à Venezuela com os filhos. Para ela, não havia nenhuma vantagem de estar no Brasil passando necessidades econômicas, assim como passavam na Venezuela. Miguel, determinado, sempre dizia que iria aguentar até onde desse: "Vamos esperar até dezembro 2014, se as coisas não melhorarem, a gente volta!".

Ao esposo Miguel, então, foi sugerido por um agente da Polícia Federal em Manaus que o mesmo fizesse a solicitação de refúgio. Ele foi um dos primeiros setenta venezuelanos que deram entrada no pedido de refúgio ao longo de 2014 no Brasil, cifra muito distante dos 142.889 processos registrados até dezembro de $2020^{3}$. Já com o protocolo de solicitação de refúgio na mão, ele foi capaz de deixar de trabalhar informalmente na rua vendendo água e conseguiu seu primeiro trabalho com "carteira assinada" em uma revendedora de automóveis. Em 2015, passados os três meses de experiência e confirmada a admissão na empresa, Rosa retornou com os filhos para junto do marido. Desde então, foram vários trabalhos como: recepcionista, segurança, garçom, entregador de pizza e auxiliar de administração em um condomínio de classe média alta. Eram trabalhos suficientes para o sustento da família, mas distantes da formação acadêmica e da experiência profissional obtida na Venezuela.

No ano 2015, conheceram um casal de estudantes colombianos que lançaram a sugestão para participarem dos processos seletivos para bolsas de Pós-Graduação. O jovem era bolsista na Universidade Estadual do Amazonas (UEA) por meio do programa PAEC - OEA ${ }^{4}$. Aquela ideia foi a melhor proposta obtida até então para dar continuidade a uma atividade econômica relacionada com as qualificações profissionais de Miguel e Rosa. Não vislumbravam, à época, a mais remota possibilidade de revalidar os diplomas de bacharéis em Direito já que era um processo demorado e caro por causa da necessidade de tradução. Além disso, a informação sobre o assunto nas instituições de ensino superior brasileiras era pouco acessível.

3 Para dados estatísticos ver a Plataforma de Coordenação para Refugiados e Migrantes da Venezuela (R4V), disponível em: <https://r4v.info/es/situations/platform/location/7509>, consultada em 27.01.2021.

4 Lançado em 2011, o Programa de Alianças para a Educação e a Capacitação (Bolsas Brasil - PAEC OEA-GCUB) é resultado da cooperação entre a Organização dos Estados Americanos (OEA), a Organização Pan-Americana da Saúde (OPAS/OMS) e o Grupo Coimbra de Universidades Brasileiras (GCUB), com apoio do Ministério das Relações Exteriores do Brasil (MRE). Para mais informações ver: <http://www.grupocoimbra.org.br>. 
Avaliaram os preços dos cursos de pós-graduação em faculdades particulares para dar uma "adequação" aos currículos estrangeiros com um pouco de experiência acadêmica no Brasil e, assim, Miguel conseguiu fazer uma especialização em Docência do Ensino Superior e Rosa um MBA em Gestão de Pessoas, ambos em faculdade particular. Atualmente, Rosa enfrenta o desafio de mergulhar no mundo da Antropologia Social, em uma universidade pública, por meio de bolsa PAEC-OEA. Sua aproximação com a Antropologia se deu graças ao ativismo do professor Sidney Silva (UFAM), coordenador do Grupo de Estudos Migratórios na Amazônia (GEMA) que realiza anualmente eventos para discutir os desafios colocados pelos diferentes fluxos migratórios às políticas públicas em Manaus e no Amazonas.

Miguel, por sua vez, conseguiu revalidar o seu diploma de bacharel em Direito pela Universidade Federal do Amazonas e cursa o mestrado em Segurança Pública, também em universidade pública. No momento presente (janeiro de 2021), ele presta serviços para uma ONG que atua no acolhimento de migrantes venezuelanos. Além disso, o casal participa de uma associação de venezuelanos que tem como objetivo principal informar e capacitar os compatriotas para lidar com as peculiaridades burocráticas no Brasil. Vale destacar o serviço voluntário de auxílio a outros/as venezuelanos/as para entrada com processos de revalidação de diploma de ensino superior.

Em novembro de 2018, nasceu a pequena Eduarda. Primeira filha brasileira do casal. Para ajudar nos cuidados iniciais com a bebê, os avós maternos também vieram ao Brasil. Os avós deram entrada no pedido de refúgio e ficaram no Brasil durante um ano inteiro, retornando à Venezuela no final de 2019, pois não podiam deixar a casa abandonada sob o risco de ocupação e/ou depredação de seu patrimônio. O vovô, empresário do ramo da construção civil, vive na Venezuela com as economias conquistadas ao longo da vida e sentiu o peso da diferença de poder de compra da moeda venezuelana no Brasil. Antes, quando viajava como turista, utilizava com frequência a expressão: "Tá barato, dá-me dos"5. Com a desvalorização abissal do Bolívar, viu-se na incômoda posição de ter sua estadia no Brasil financiada pela filha bolsista. A vovó, também acostumada a uma vida de confortos materiais, como a ampla casa de praia em Cumaná, precisou se adaptar à nova realidade da família em Manaus, dividindo com o marido, a filha, genro e netos o pequeno apartamento de dois quartos localizado em um bairro afastado do centro.

A trajetória da família Jimenez no Brasil é mais uma história de metamorfoses e superações de vulnerabilidades face ao processo migratório transnacional. Como argumenta o sociólogo Leonardo Cavalcanti, à luz do pensamento de Abdelmalek Sayad, o migrante experimenta uma "inconsistência de status" que abarca aspectos

\footnotetext{
Expressão empregada por venezuelanos/as, de forma anedótica, para demonstrar que o poder de compra da moeda venezuelana, no auge da bonança petroleira, podia comprar o dobro de qualquer produto oferecido em lojas e centros comerciais estrangeiros.
} 
socioeconômicos, jurídicos e culturais. No âmbito laboral, sobretudo, é comum exercerem "atividades aquém das suas formações e experiências nos países de origem" (Cavalcanti, 2015, p. 28).

O nascimento da menina, cidadã brasileira jus soli, abriu a possibilidade de uma nova modificação no status jurídico dos progenitores e dos irmãos mais velhos que puderam, a partir de então, solicitar um visto de permanência no país, não mais estando atrelados à "solicitação de refúgio" ou à "residência temporária" para cidadãos transfronteiriços. Como bem argumenta Didier Fassin (2014), a vida do migrante transnacional é caracterizada por uma jornada contínua em busca de reconhecimento e autoafirmação enquanto sujeitos de direitos diante dos entraves burocráticos enfrentados no país de destino.

\section{Da migração como projeto familiar}

Nesse breve ensaio deixamos antever um tema clássico das ciências sociais: a discussão envolvendo a dicotomia indivíduo-sociedade. Desde Emile Durkheim, noções de solidariedade e lealdade ao grupo levantam sombra sobre as ações das pessoas. Max Weber, por sua vez, argumentava que os homens vivem presos a teias de significados que eles mesmo construíram e autores marxistas vêm persistindo há mais de um século na busca de motivações estruturais para os comportamentos individuais. Se estamos ou não fadados a dançar conforme a música tocada por outras pessoas, não se pode afastar o fato de que a performance do dançarino também interfere no ritmo da banda. Em última análise é sempre a pessoa, e não o grupo, quem tem o poder da ação. O paradoxo não se esgota uma vez que o sujeito, ator, agente, ele próprio tem um lugar de fala, uma posição hierárquica, seu quinhão de participação nos arranjos coletivos. Como diria Gregory Bateson (1972), trata-se de uma situação de duplo vínculo: do compromisso paradoxal (e inescapável) do indivíduo com seus desejos, por um lado, e sua subordinação e dependência aos desejos de outrem, por outro.

Ainda que as "sociedades" não sejam isoláveis para observação de sua conduta em laboratório, é preciso que os cientistas sociais se esforcem para traçar as interconexões existentes entre as pessoas. O francês Bruno Latour aponta para a necessidade de se promover um reagrupamento do social, não mais tomando esse "social" como algo dado, abstrato, porém como um coletivo observável de relações em constante movimento. Para ele não haveria grupos, sociedade, não haveria um todo para ser artificialmente reconstruído pelos pesquisadores (Latour, 2012). Resgatando a monadologia de Gabriel Tarde, Latour propõe que somente podemos encontrar "grupos em formação", agregados de associações entre pessoas, ideias e coisas acontecendo em algum momento e lugar.

Os movimentos globais, como os fluxos migratórios, também podem ser pensados nesse sentido. De acordo com Latour, o global é sempre "localizável" e o local é sempre "globalizável". Anna Tsing, antropóloga norte-americana, sugere 
situar esse global no tempo e no espaço por meio do conceito de "projeto". Por "projeto" ela entende "a relatively coherent bundles of ideas and practices as realized in particular times and places" (Tsing, 2008, p. 85). Um projeto "localiza" o global, pois oferece materialidade para o fenômeno abstrato. Pode ser visualizado como um agregado de associações envolvendo pessoas, coisas e ideias; diferentes agências concorrendo em torno de uma causa, em determinado momento e lugar.

Desde um ponto de vista individual-biográfico, Gilberto Velho (2013b, p. 132) emprega a noção de projeto como "uma conduta organizada para alcançar finalidades específicas". O antropólogo aborda a noção de indivíduo enquanto um valor dominante no contexto urbano-industrial. Nesse sentido, o indivíduo seria marcado por suas escolhas pessoais e trajetória indivisível e inconfundível com a trajetória de outrem. Pode-se dizer que um "indivíduo", na cultura ocidental, é o protagonista em seu próprio filme ou narrativa/percurso individual que tem passado, presente e futuro.

Por outro lado, ainda que indivíduo, Velho reconhece que este agente está inserido em um agregado social complexo no seio do qual se depara cotidianamente com sistemas de valores e práticas heterogêneos que, em suas diferenças, o conduzem a uma constante negociação. Deriva deste entendimento que o indivíduo não está solitário num mundo conformado por muitos indivíduos, logo, não podendo se restringir a noção de projeto à esfera da vontade pessoal. O indivíduo, com suas memórias e aspirações, se depara com as memórias e aspirações de outros indivíduos dentro de um "campo de possibilidades" que oportuniza um leque restrito de alternativas. Este campo de possibilidade diz respeito a processos sócio-históricos de longa duração que ultrapassam as idiossincrasias individuais, implicando também a coexistência de outros projetos individuais e também coletivos (Velho, 2013b).

O "projeto" aqui em questão é um "projeto coletivo" ou um "projeto familiar" que diz respeito ao bem-estar dos membros da família Jimenez, em deslocamento da Venezuela para o Brasil. Isto não significa dizer que todos os membros do agregado social que chamamos aqui de "família Jimenez" participem de maneira homogênea desse projeto coletivo. Como alertava Gilberto Velho, existem diferenciações "devido a particularidades de status, trajetória e, no caso de uma família, de gênero e geração" (Velho, 2013b, p. 133). O lugar de cada indivíduo no projeto coletivo pode ser conhecido no processo de tomada de decisões, quando uma pessoa captura para si o poder de fazer escolhas em nome das outras.

As crianças, no caso em tela, não foram sequer consultadas em relação à sua participação no "projeto". Os pais decidem pelas crianças. A socióloga chilena Iskra Pavez-Soto, em revisão teórica sobre infância e migrações, chama atenção que as vontades e expectativas dos pequenos não costumam ser levados em consideração pelos adultos no processo decisório de mudar de casa, de vizinhança, de cidade ou mudar de país. Ainda que os pais insistam no discurso de que suas decisões 
foram tomadas em nome e em benefício dos filhos, a prole fica em condição subalternizada e sua voz é silenciada na construção e realização do "projeto migratório familiar" (Pavez-Soto, 2017).

Retomando a leitura realizada por Anna Tsing, vale dizer que um "projeto", enquanto agregado de associações entre pessoas, coisas e ideias, situável no tempo e no espaço, não deixa de constituir e ser constituído por uma paisagem repleta de controvérsias e fricções. A mais fundamental dessas controvérsias, no nosso entendimento, está na base do próprio reconhecimento de um coletivo denominado "família".

Mas que ideia de "família" é essa? Quem faz parte da família? Estas perguntas ocupam as reflexões de diversos/as autores/as e temos reforçada a certeza de que elas devem sempre ser refeitas por quem estuda famílias e movimentos migratórios. Iana Vasconcelos e Sandro Almeida Santos (2017) abordam essa pergunta trazendo as diferentes construções da categoria "família" para o centro da discussão, por meio de um exercício comparativo entre garimpeiros na fronteira Brasil-Venezuela e remanescentes de comunidades alternativas no planalto central brasileiro. Pode-se dizer que não existe um modelo de "família" a priori, mas sim uma diversidade de culturas de parentesco a serem conhecidas. As relações de parentesco e, por conseguinte, a família, devem ser pensados aqui como agregados de associações que se diferem de outros "grupos em formação" por suas metáforas sobre conectividade e mutualidade, bem como pela tendência ao desenvolvimento de vínculos duradouros de lealdade e afetividade. Vínculos e narrativas que precisam ser reforçados e celebrados periodicamente, sob pena de ruptura (Carsten, 2000; Fonseca, 2007; Vasconcelos, Santos, 2017).

O parentesco é uma chave profícua para pensar os fluxos migratórios uma vez que permite focalizar as alianças e substâncias que mantém as pessoas conectadas entre si, reconhecendo-se mutuamente como partes de uma mesma família. Noções e práticas de família variam conforme o contexto cultural estudado. No caso de famílias em trânsito, existe uma ênfase nos cuidados à distância, nas remessas (monetárias ou não) e nas modalidades de acolhimento no país estrangeiro. As famílias venezuelanas, uma vez no Brasil, precisam estabelecer os meios para conseguir moradia e trabalho aqui, ao mesmo tempo em que necessitam enviar alimento e informações ao seu país de origem. O projeto migratório é uma mobilização coletiva. Quando há sucesso dos pioneiros, a rede de parentesco tende a crescer no local receptor. Assim vem acontecendo com as parentelas venezuelanas que se aventuram além das fronteiras com o Brasil, chegando ao estado do Amazonas e ampliando seus horizontes para outras localidades.

O estudo sobre famílias de migrantes transnacionais ou, resumidamente, "famílias transnacionais", implica na articulação de três dimensões de análise: a "família", a "nação" e o "transnacional". Acompanhamos as sugestões de Ribeiro (2008), para quem os movimentos entre as fronteiras nacionais impõem aos/às 
pesquisadores/as a necessidade de observar as trajetórias identitárias dos indivíduos e a negociação constante entre as dimensões do local, do nacional e do global. Essa trajetória do local ao global passando pelo nacional é também uma trajetória que parte de relações concretas - compartilhadas num tempo e espaço determinado - e alcança relações mais abstratas - sem tempo e espaço determinados (Eriksen, 2014, p. 29-30).

Ao incluir o problema abstrato da transnacionalidade, os termos e as relações de parentesco devem ser pensados em sua interface com as diferentes nacionalidades e o trânsito entre elas. Partindo do argumento que a família é uma unidade social que produz uma ficção de unidade natural (raramente contestada), as antropólogas Deborah Bryceson e Ulla Vuorella (2002, p. 10-11) sugerem que as famílias, assim como as nações, podem ser pensadas enquanto "comunidades imaginadas" delimitadas por fronteiras e vistos próprios. Em suas palavras: "one can alter one's nationality and citizenship just as one can alter one's family and its membership in everyday life" (Bryceson, Vuorella, 2002, p. 10). A família se diferencia da nação por ser a comunidade imediata de um indivíduo. Ela pode ser pensada como transnacional quando o agregado social atravessa duas ou mais nacionalidades e as relações passam a ser mediadas por fronteiras e vistos nacionais, além daqueles que a família estabelece para si. Localmente, o pertencimento a uma família é independente do pertencimento nacional, porém a experiência da transnacionalidade nos arranjos familiares só pode existir acionando-se as nacionalidades para atravessá-las e borrar suas fronteiras.

Atravessar as nacionalidades, contudo, não se dá sem resistência. Ainda que o conceito de nação seja de natureza abstrata, ele se faz razoavelmente concreto por meio das diferentes instituições e burocracias estatais. A mobilidade e a comunicação transnacionais são mediadas pelas moedas, documentos e outros filtros colocados pelos Estados-nação, como analisa Díaz Crovetto (2015) a partir das condicionantes ao embarque/desembarque de tripulantes chilenos a serviço de navios panamenhos em portos espanhóis e africanos. Note-se que os documentos e as legalidades pertencem à dimensão do nacional. Até mesmo os oceanos estão cercados pelas nacionalidades.

O manejo da relação com as instituições nacionais (polícias, moedas, passaportes, receitas federais, etc.) é constituinte das estratégias de mobilidade e comunicação das "famílias transnacionais". Desde a decisão por viajar, passando pela viagem de ida, o estabelecimento no local de destino até a possibilidade de manter relações à distância com o país de origem ou um eventual retorno, o migrante é chamado a lidar com as diferentes estruturas normativas nacionais. É importante conhecermos as estratégias utilizadas pelas famílias para se adequar ou se esquivar das legalidades, tornando possível o movimento de pessoas, mercadorias e informações. No caso de Miguel e Rosa, a solicitação de refúgio foi utilizada como estratégia para permitir acesso à documentação trabalhista que o visto de estudante não concedia. 
Além da relação com as burocracias, as famílias desenvolvem mecanismos para minimizar os efeitos da distância geográfica entre as pessoas e preservar a proximidade afetiva, o que Loretta Baldassar (2008) chama de "co-presença". Trata-se da sensação de presença à distância criada pela telecomunicação, pela remessa de dinheiro, bens de consumo e outras formas de cuidados. As remessas monetárias, sobretudo, promovem uma sensação continuada de presença quando elas permitem intervenção e transformação nas condições de saúde e nas condições econômicas da família na origem. Até mesmo coisas (roupas, ferramentas, fotografias, recortes de jornal, etc.) podem ser elencadas como indicadores de "co-presença".

Refletindo sobre a relação entre os deslocamentos humanos e o parentesco, com base em suas pesquisas com brasileiros que vivem em Portugal, Igor Machado sugere que "estando longe, o que produz a relação (o próprio parentesco) não é mais a convivência e o sangue, mas o envio de sinais diacríticos de presença e interesse no núcleo familiar (remessas, bens, telefonemas, e-mails, vídeos)" (Machado, 2015, p. 202). Tais "sinais de presença e interesse" aparecem como indicadores etnograficamente apreensíveis das relações que fabricam o parentesco, influenciando na percepção da "distância" relativa. Para Andrea Lobo, que estudou a relação entre fluxos migratórios e parentesco em Cabo Verde, a comunicação afetuosa continuada e as remessas financeiras ou culturais reforçam os vínculos interpessoais, aproximando metaforicamente aqueles que estão longe (Lobo, 2012). Estar perto ou longe, nesse sentido, não é uma distância medida em quilometragem, porém uma condição medida pela frequência da comunicação e pelo interesse mútuo demonstrado na própria continuidade da relação (Vasconcelos, Santos, 2017).

As remessas de migrantes venezuelanos, em virtude da acentuada escassez de gêneros alimentícios que marcou a Venezuela entre os anos 2016 e 2019, vêm se caracterizando por remessas de itens alimentícios em grandes encomendas de pacotes fechados. São fardos de arroz, macarrão, açúcar, óleo vegetal e bebidas. Também os medicamentos entram no rol das remessas para aqueles parentes que possuem doenças crônicas e não podem interromper tratamento. Existem, ainda, as transferências monetárias utilizando meios alternativos que não passam pelo sistema bancário oficial da Venezuela. Mas as remessas em dinheiro são menos confiáveis, pois a inflação galopante no país de origem faz com que o valor depositado perca o seu poder de compra rapidamente, uma vez realizada a conversão à moeda local. O alimento e o remédio, transportados por amigos ou por intermediários que se especializaram nesse serviço, atendem melhor à intenção inicial quando chegam ao destino final.

Ainda no escopo das relações à distância, Peggy Levitt chama atenção para as remessas culturais e sociais que seriam a divulgação de práticas e ideologias do contexto de destino para o contexto de origem (Levitt, 2001, p. 54). Assim como o/a migrante leva sua cultura ao local de destino, ali ele/ela aprende coisas novas e transmite aos seus familiares na origem. Nessa via de mão dupla são 
intercambiados estruturas normativas, sistemas de práticas, capital social, etc.. Levitt oferece como exemplo a influência cultural e política exercida na República Dominicana por cidadãos dominicanos que vivem nos EUA (Levitt, 2001, p. 62).

Os/as venezuelanos/as que vivem no exterior vêm se organizando para, mesmo à distância, pressionar por mudanças políticas na Venezuela (Paez, 2016). Em Manaus, de tempos em tempos, em datas significativas como eleições ou no chamado Dia de la Pátria (Dia da Independência), acontecem mobilizações que reúnem centenas de migrantes em praças e outros espaços públicos, para protestar contra o governo de Nicolás Maduro. Os/as venezuelanos acreditam que uma mudança no regime político em seu país pode significar uma oportunidade para reconstrução das bases econômicas e jurídicas do Estado. O que possibilitaria, numa perspectiva otimista, o retorno daqueles grupos que fugiram das degradadas condições de vida na Venezuela.

De modo geral as famílias conseguem manejar as fronteiras políticas, sociais e culturais que se apresentam como desafio. Isto é tornado possível considerando que esse "grupo em formação" exibe plasticidade em sua constituição. De acordo com Machado, "as decisões de migrar têm relações profundas com os processos de fissão e fusão de núcleos familiares, com sua constante movimentação de fronteiras entre pessoas de mesmas famílias" (Machado, 2015, p. 202).

No caso da família Jimenez, temos um modelo "ocidental" de família nuclear cujo esforço maior é para continuarem vivendo todos juntos sob um mesmo teto, seja na Venezuela ou no Brasil. O pai esteve sozinho no Brasil por poucos meses. Assim que conseguiu alguma estabilidade financeira, a mãe trouxe os filhos. A prioridade, naquele momento, em 2014, era garantir o bem-estar dos dois meninos - ainda que as crianças não fossem consultadas sobre a mudança. A fala da mãe é emblemática nesse sentido. Se as coisas não dessem certo no Brasil, a tendência seria retornarem os quatro para a Venezuela. Entre sofrer em Manaus ou sofrer em Maracay, melhor estarem juntos aos demais parentes da família extensa. Uma vez que a situação foi se transformando em favorável à permanência no Brasil, o casal optou por conceber mais uma criança.

Nascida brasileira, a bebê legitimou o direito de residência permanente e abriu um novo campo de possibilidades para o projeto da família Jimenez. Desenvolvendo discussão teórica sobre os conceitos de "vida nua" e "vida plena" do filósofo Giorgio Agamben, o antropólogo Didier Fassin argumenta que a condição de "solicitantes de refúgio" ou "refugiados" situa o indivíduo em uma condição de "vida nua", "desprovidos de seus direitos humanos pela falta de cidadania, eles podem apenas clamar por permanecerem vivos" (Fassin, 2014, p. 6). A transformação do status jurídico de refugiado para residente permanente ofereceu ao casal Jimenez um primeiro passo para o almejado reconhecimento de sua presença no Brasil enquanto cidadãos com direitos políticos (vida plena), e não somente direito à sobrevivência. 
"Para onde vou com a minha família?" é um questionamento comum a diversos agregados-famílias de venezuelanos no Brasil. Há gente vivendo em praças, ruas, albergues, abrigos disciplinados pelas Forças Armadas e pela ONU, abrigos oferecidos por entidades religiosas, entre outros locais. São muitas crianças brincando, dormindo e se alimentando em ambientes insalubres. Retomando a ideia de "projeto", qual seria então o projeto da família Jimenez? Pode-se dizer que a construção desse projeto familiar encontra-se fundada na intenção de garantir um pretendido bem-estar das crianças, aproveitando as alternativas de vida abertas pela migração para o Brasil. É preciso conduzir a "família" até um local onde a fome e a desesperança não venham lhes ameaçar, onde seja possível viver uma "vida plena" e não somente uma "vida nua".

\section{Considerações finais: sobre projetos, possibilidades e transformações}

Deixamos, propositalmente, a noção de metamorfose (Velho, 2013b) para debater ao final deste artigo sobre as transformações às quais os indivíduos e os coletivos se submetem no percurso de um "projeto migratório familiar". Para Gilberto Velho, a noção de metamorfose está intimamente ligada às ideias de "projeto" (no sentido individualista) e "campos de possibilidade", pois, dadas as possibilidades de continuação de um determinado projeto, o indivíduo ou o coletivo é provocado a demonstrar o seu potencial de metamorfose, confrontando e se adaptando às diferentes condicionantes colocadas às suas aspirações iniciais. "Os projetos, como as pessoas, mudam. Ou as pessoas mudam através de seus projetos" (Velho, 2013b, p. 138).

Conforme os exemplos fornecidos por Miguel e Rosa Jimenez, com seus filhos, observamos que um projeto coletivo, um "projeto familiar", não pode mesmo ser continuado da maneira que começou. As aspirações iniciais do casal elencavam Manaus enquanto local acolhedor tendo em vista uma experiência anterior como turistas. Quando saíram da Venezuela e chegaram ao Brasil para residir, em condições de vulnerabilidade socioeconômica, perceberam que as dificuldades seriam intensas. Foram algumas idas e vindas da mulher com os filhos, alternando entre a possibilidade de seguir vivendo na Venezuela e as aspirações por viver uma vida mais próspera em território brasileiro.

Pensando o "projeto" enquanto um exercício analítico de localizar um evento transnacional, o mesmo está sujeito a constantes transformações contextuais. A chegada de Eduarda, a bebê, no "projeto" da família Jimenez, desencadeou uma série de mudanças nas relações dos papais venezuelanos com o Estado brasileiro. Eduarda é, ao mesmo tempo, causa e efeito do "projeto familiar" em alcançar estabilidade de residência no Brasil. Ela é causa porque o seu nascimento produziu o efeito jurídico necessário para legitimação da estadia dos pais que deixam de ser simplesmente "estrangeiros" para ingressar na categoria de responsáveis legais por uma criança brasileira. Mas Eduarda também é efeito desse "projeto", uma vez que 
o casal, com os filhos mais velhos, perseverou no Brasil, mesmo em condições de acentuada vulnerabilidade, e decidiu se estabelecer em Manaus.

Refletindo sobre o estado atual desse "projeto migratório familiar", considerando as transformações já enfrentadas, é possível dizer que o mesmo se encontra num momento de busca pela afirmação de uma "vida plena". O casal pretende se empoderar enquanto cidadãos no Brasil e almeja conquistar uma posição socioeconômica mais condizente (ou pelo menos, mais aproximada) com suas qualificações profissionais. Trata-se de uma metamorfose na própria condição de existência enquanto migrantes e pessoas em vulnerabilidade. Passados os momentos iniciais da experiência no Brasil, quando a luta pela sobrevivência era o objetivo maior, cinco anos depois objetivam participar da vida política no país receptor bem como conquistar uma vida economicamente independente da filantropia e da assistência estatal.

Retomando a indagação que dá título a este artigo, "para onde vou com a minha família?", entre idas e vindas de Maracay a Manaus, o casal Jimenez decidiu se estabelecer com os filhos no Brasil. Como vimos, não foram poucas as adversidades enfrentadas nos planos socioeconômico, jurídico-político e cultural. O lugar seguro para onde levar os entes queridos não está dado para nenhum/a migrante, e precisa ser construído laboriosamente. Os indivíduos e os grupos em (trans)formação aprendem a lidar com a alteridade em diferentes frentes: legislação, idioma, costumes, crenças, conceitos e preconceitos. E aprendem, sobretudo, a renascer sucessivamente por meio das inúmeras metamorfoses em suas vidas.

\section{Referências bibliográficas}

BALDASSAR, Loretta. Missing Kin and Longing to be Together: Emotions and the Construction of Co-presence in Transnational Relationships. Journal of Intercultural Studies, v. 29, n. 3, p. 247-266, 2008.

BATESON, Gregory. Steps to an Ecology of Mind: Collected Essays in Anthropology, Psychiatry, Evolution, and Epistemology. Chicago: University of Chicago Press, 1972.

BRYCESON, Deborah; VUORELLA, Ulla. Transnational families in the twenty-first century. In: BRYCESON, Deborah; VUORELLA, Ulla (eds.). The transnational family: new european frontiers and global networkings. New York: Berg, 2002, p. 3-30.

CARSTEN, Janet. Introduction: cultures of relatedness. In: CARSTEN, Janet (org.). Cultures of Relatedness: new approaches to the study of kinship. Edinburgh: Cambridge University Press, p. 1-36, 2000.

CAVALCANTI, Leonardo. Novos fluxos migratórios para o mercado de trabalho brasileiro. Desafios para políticas públicas. Revista da Associação Nacional de PósGraduação e Pesquisa em Geografia, v. 11, n. 16, p. 21-35, 2015. DOI: 10.5418/ RA2015.1116.0002.

COSTA, João Carlos Pinto. A autoetnografia como opção metodológica no estudo antropológico das situações de vulnerabilidade: exemplo de um caso de hipotireoidismo. Revista Pesquisa Qualitativa, v. 5, n. 8, p. 290-311, 2017. 
DíAZ CROVETTO, Gonzalo. Entre lugares y documentos: problematizando el desplazamiento y las condiciones transnacionales del viaje y del trabajo de tripulantes corraleños (Chile). Antipoda - Revista de Antropología y Arqueologia, v. 23, p. 23-44, 2015. DOI: 10.7440/antipoda23.2015.02.

ERIKSEN, Thomas Hylland. Globalization: the key concepts. London: Bloomsbury, 2014.

FASSIN, Didier. Compaixão e Repressão: A Economia Moral das Políticas de Imigração na França. Ponto Urbe [Online], n. 15, 2014. DOI: 10.4000/pontourbe.2467.

FONSECA, Cláudia. Apresentação - De família, reprodução e parentesco: algumas considerações. Cadernos Pagu, n. 29, p. 9-35, 2007.

LATOUR, Bruno. Reagregando o social: uma introdução à teoria do ator-rede. Salvador: EdUFBA, 2012.

LEVITT, Peggy. The transnational villagers. Los Angeles: University of California Press, 2001.

LOBO, Andréa. Tão Longe, Tão Perto: famílias e 'movimentos' na Ilha da Boa Vista de Cabo Verde. Brasília: ABA Publicações, 2012.

MACHADO, Igor. Movimentos e parentesco: a variação da diferença em quatro casos. In: MACHADO, Igor (org.). Deslocamentos e parentesco. São Carlos: EdUFSCar, 2015, p. 195-210.

PAEZ, Thomas. La voz de la diáspora venezolana. Caracas: El Estilete, 2016.

PÁVEZ SOTO, Iskra. La niñez en las migraciones globales: perspectivas teóricas para analizar su participación. Tla-melaua, v. 10, n. 41, p. 96-113, 2017.

PEDONE, Claudia. "Varones aventureros vs. madres que abandonan": reconstrucción de las relaciones familiares a partir de la migración ecuatoriana. REMHU, Revista Interdisciplinar da Mobilidade Humana, v. 6, n. 30, p. 45-64, 2008.

RIBEIRO, Gustavo Lins. Do nacional ao global: uma trajetória. Série Antropologia, v. 422, Brasília: DAN/UnB, 2008.

STRATHERN, Marilyn. Os limites da autoantropologia. In: STRATHERN, Marilyn. O efeito etnográfico e outros ensaios. São Paulo: Cosac Naify, 2014, p. 133-158.

TSING, Anna. The global situation. In: INDA, Jonathan Xavier; ROSALDO, Renato. (eds.). The anthropology of globalization: a reader. Oxford: Blackwell Publishing, 2008, p. 66-98.

VASCONCELOS, lana; SANTOS, Sandro Almeida. Quem é da família? Reflexões sobre parentesco e mobilidade. REMHU, Revista Interdisciplinar da Mobilidade Humana, v. 25, n. 49, p. 249-266, 2017.

VELHO, Gilberto. Observando o familiar. In: VELHO, Gilberto. Um antropólogo na cidade: ensaios de antropologia urbana. Rio de Janeiro: Zahar, p. 69-79, 2013a.

VELHO, Gilberto. Trajetória individual e campo de possibilidades. In: VELHO, Gilberto. Um antropólogo na cidade: ensaios de antropologia urbana. Rio de Janeiro: Zahar, 2013b, p. 125-138.

VIVAS, Leonardo; PAEZ, Thomas. The venezuelan diaspora: another impending crisis? Freedom House Repport, 2017. DOI: 10.13140/RG.2.2.17819.87843. 